DOI: https://doi.org/10.47405/aswj.v5i4.154

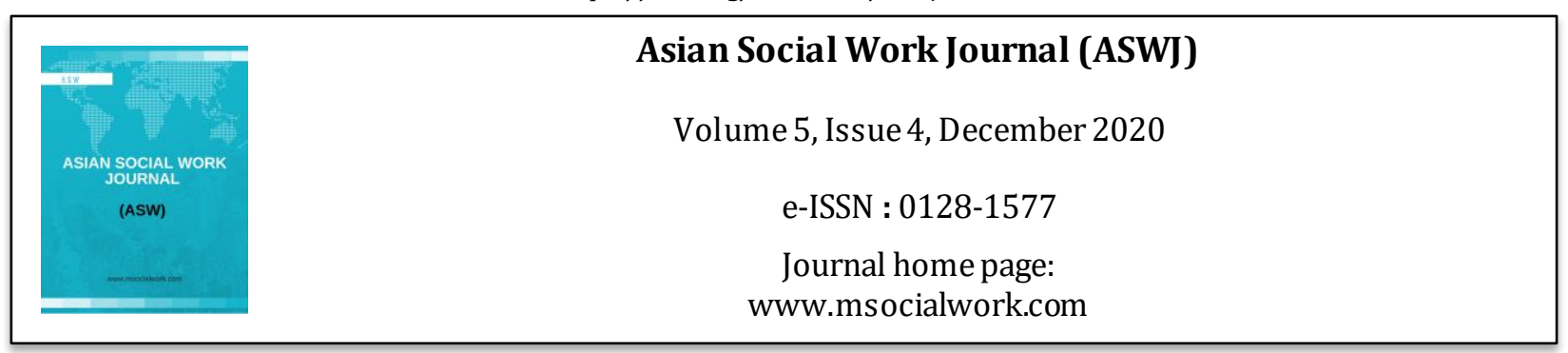

\title{
The Structural Inequalities, Anti-Oppressive and Anti-Discriminatory Approaches Associated with the Marginalization of Asylum Seekers in Australian Historical Context: An Overview
}

\author{
Niket Paudel ${ }^{1}$ \\ 1University of Wollongong, Australia \\ Correspondence: Niket Paudel (niket.paudel@gmail.com)
}

\begin{abstract}
Asylum seekers still endure a lot of oppression and alienation, with many erroneous assumptions about them circulating not only in Australia but throughout the world. Asylum seekers are deemed illegal due to the lack of their legitimate visas and are overlooked. The anti-oppressive theory seeks to oppose the underlying institutional and structural challenges in society and power to maintain power balance among minorities. The approach is focused on social justice. Social justice is attained by improving not only the quality of life but also the wellbeing of micro, macro, and mezzo levels with this approach. The fundamental value of diversity is also maintained. The abuse of power among the members of the society with regards to asylum seekers strengthens the notion of oppression; hence the approach strives for the power redistribution by not only defying the structures but also by advocating for the rights of the oppressed. The oppression can arise because of the traditional functioning ways of the systems or individuals' bigotry. Asylum seekers in Australia are marginalized by the structure through their stern policies and by individual's bigotry through their hate and sense of threat.
\end{abstract}

Keywords: Asylum seekers, inequalities, anti-oppressive, marginalization

\section{SHORT COMMUNICATION}

\section{Overview of the Structural Inequalities that deter Social Inclusion:}

Australian history with people seeking asylum has been worrying and troubling with the enactment of constricting measures for daunting the arrival of asylum seekers (Philips, 2015). It was not until 1992 where Australia enacted the obligatory detaining policy of asylum seekers who entered via boat without a legally binding visa (Australian Human Rights Commission, 2004). A colossal quantity of boat arrivals resulted in Australia introducing this policy.

The government did not put an end to violence and inhumaneness. 1996-2007 witnessed Australia's policy chastising and penalizing the asylum seekers who entered Australia via boat (Phillips and Spinks, Boat arrivals in Australia since 1976 2013). This occurred under the Coalition government. The onshore centers were expanded to isolated localities for detention. Nauru and Manus Island were made the offshore detention centers (Karlsen, 2016). The establishment of Temporary Protection Visas (TPV) for individuals who were refugees and who could acquire Australia's refugee protection measures happened under the Coalition government too. John Howard stated that the decision to let people inside Australia and the circumstance in which they arrive will be decided by the Australians. 
DOI: https://doi.org/10.47405/aswj.v5i4.154

John Howard's quote became the catchphrase of the conservative government (Marr \& Doherty, 2011). The procedures and strategies during the Conservative government were deemed more humane. The removal of TPV occurred right after the election. There was a massive upsurge in the number of people who arrived via boat which led the Labor government to ditch its pledge to more benevolent policies towards asylum seekers in mid-2012 (Hartley et al., 2013). This resulted in the re-establishment of the penal policies, from offshore processing to arrival detentions in Australia (Hartley et al., 2013).

In 2013, the policy was tightened and became progressively more penal after the Coalition government gained power; 'Operation Sovereign Borders', a militarized operation was implemented (Gauja et al., 2018). This operation involved Australia maritime workforces prohibiting and turning back asylum seekers who made the journey via boats where authorities from Sri Lanka, Indonesia, and Malaysia worked collaboratively with Australia during this operation (Medhora \& Doherty, 2015). One of many strict procedures, denying access to family to reunite with those who arrived via boat was incorporated during the operation. They could not reunite with family unless they became Australian citizens (Refugee Council of Australia, 2020). Furthermore, the boat arrivals were refused access to legal aid subsidized by the government. The government also passed a contentious bill of restoration of Temporary Protection Visas (Refugee Council of Australia, 2019). Moreover, the government propounded a bill that confiscated asylum seeker's access to independent assessments and evaluations of their immigrant appeals. Additionally, the reference to UNRC in domestic law was stripped after the introduction of the bill (Refugee Council of Australia, 2019).

Australia has been condemned time and again for breaching human rights concerning asylum seekers (Davidson \& Vasefi, 2018). The condemnation is more vocal in recent days. The lack of respect from the Australian government concerning international guidelines for the safeguarding of asylum seekers has made the criticism more evident in the modern-day. The penal measures have been damaging asylum seekers not only today but in the past as well. According to research by BMC Public Health, discrimination has played a major role in deteriorating the mental wellbeing of the asylum seekers (Ziersch, Due \& Walsh, 2020). The punitive measures leave asylum seekers helpless. Moreover, numerous articles and reports underlined the concern of the adverse impact on the health and wellbeing of asylum seekers in detention centers.

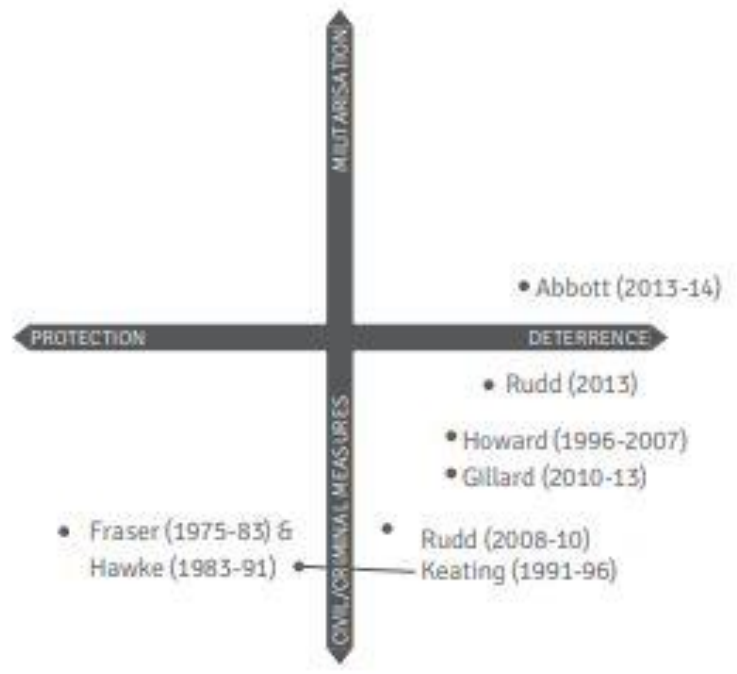

(Centre for Policy Development 2014, 18)

Not only the government but the media have also played a negative role in the reporting and coverage of asylum seekers. Those who arrive via boat are deemed as smuggled humans and are questioned about their sufferings back home, which is provoking and leads to mental trauma and torture (Phipps, 2015). The political discourse is often harsh, especially with conservative governments. There is a sense of terror among citizens as well due to the religion of the asylum seekers. Intersectionality between Islam and asylum has led to prejudices among many. Some even endorse the execution of the callous policy and advocate for harsher measures. 
DOI: https://doi.org/10.47405/aswj.v5i4.154

According to research, less that one in five respondents agreed that people who arrived via boat should be qualified for permanent settlement whereas since 2011, the representation has been in negative numbers (Markus \& Arunachalam, 2018). This shows the people wanting harsher policies for asylum seekers. The conditions in offshore detention centers have always been covered in mystery but in recent times more shreds of evidence have appeared through lived through experiences, media, and the courage of whistleblowers.

Asylum seekers still endure a lot of oppression and alienation, with many erroneous assumptions about them circulating not only in Australia but throughout the world. Asylum seekers are deemed illegal due to the lack of their legitimate visas and are overlooked (Doherty \& Hekmat, 2016). Any individual who had to fight for their lives would try to flee away from their country to save their lives with or without a visa. Asylum seekers are dubbed illegal and hostile by the Australians with the political rhetoric media supporting the act (Copland, 2014). There is a difference between 'illegal immigrants' and 'unauthorized settlers'. Asylum seekers are not aliens, as considered by various politicians and the general public. Also, there is a difference between humanitarian entrants and asylum seekers; the latter perceived as non-humans with prejudice and resentment with a sense of danger (Pedersen \& Hartley, 2015).

Fig: History of Asylum Seekers and its policy in Australia (Asylum Insight n.d.)

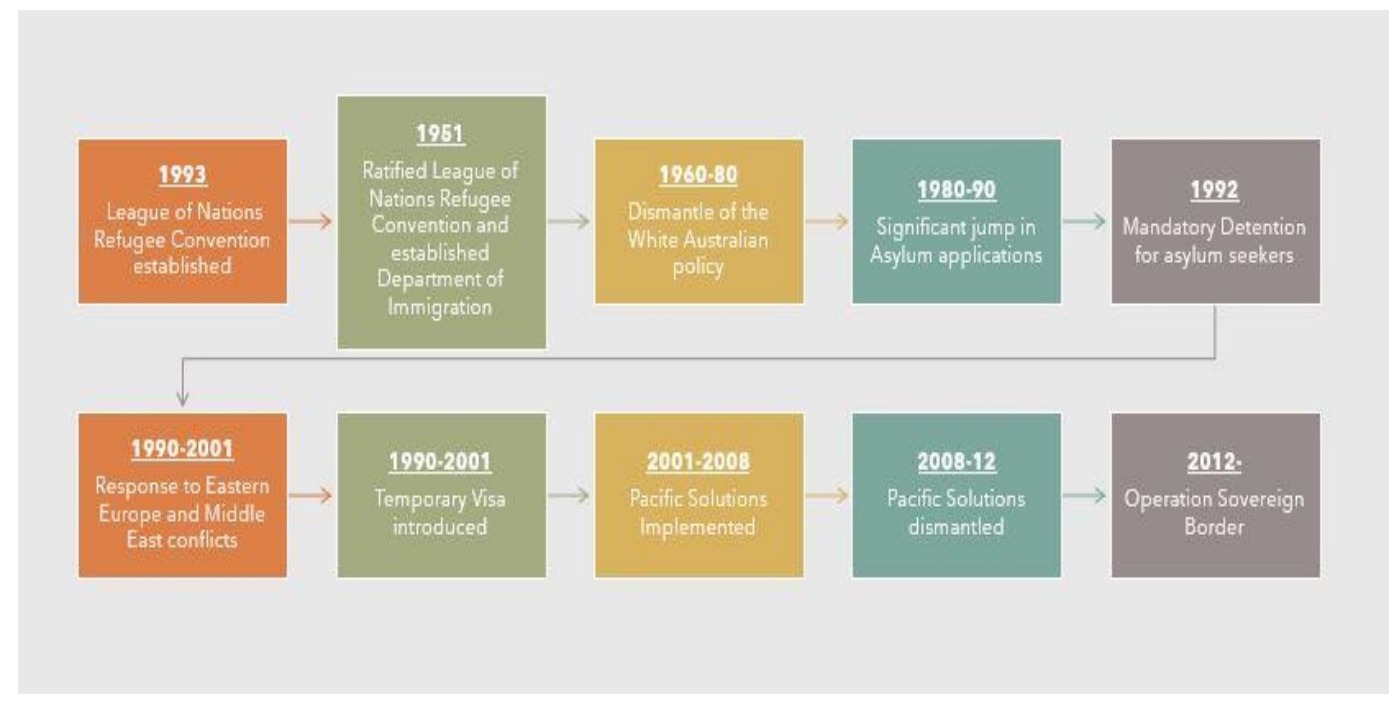

According to the Refugee Convention Article 31 (1), asylum seekers and refugees should not be discriminated against by the rationale of the illegitimate entry to a country (UNHCR, 1951). Though the Australian government argues the TPV is not a punishment, but it is barely a help. Lately, Australia classifies asylum seekers through the means of entry hence there is the existence of prejudice. Despite the Refugee Convention Article, according to the Migration Act 1958, the Australian government identifies them as aliens and illegal; applying the authority to damage the asylum seekers through inhumane detentions (Linklater, 2011). The policy put forward by the government constricts not only the movement but also the engagement of the asylum seekers which eventually adds to afflictions.

One of the many structural inequalities is the asylum seekers being detained anytime anywhere in countries like Indonesia and/or Malaysia as those countries are not signatories to the United Nations Refugee Convention unlike Australia (Topsfield, 2015). The boat travelers can be detained, arrested, imprisoned, punished, and deported by the authorities. This is problematic on numerous levels. Whenever the issues dealt by asylum seekers are raised, the focus is always on the material inequalities and how they are treated as an alien. The focus should not only be about how they are alienated but also how the TPV has been repressing their rights and limiting their participation (Taylor, 2002).

Furthermore, advocates, lawyers, and media represent the voices of the oppressed whereas asylum seekers rarely get to voice for themselves. The notion should be working 'with' the asylum seekers not 
working 'for'. Some of the structural disparities and equity barriers for the TPV holders are listed below (Marston, 2003):

i. Commonwealth Income Support: TPV holders can only access special benefit looking at the eligibility criteria whereas PPV (Permanent Protection Visa) holders have immediate access.

ii. Education: TPV holders can access primary, secondary, and TAFE education in Victoria whereas in other states full fees are imposed, unlike PPV holders where they are provided benefits like any other permanent residents.

iii. Settlement Support: TPV holders are not eligible for most of the DMIA funded services, with an exception for health screening and referral.

iv. Family Reunion: TPV holders are not allowed for family reunions, not even children and spouses.

v. Travel: TPV visa holders get their protection submission canceled even traveled after permission.

vi. Work Rights: The job search is sternly constricted by TPV.

vii. English Class: It was not until recently; TPV holders were not eligible for federally funded English language programs.

viii. Medical Benefits: TPV holders are not discriminated against in medical benefits as they are eligible for Medicare and Health Care Cards.

ix. Housing: TPV holders are not entitled to on-arrival accommodation with limited access to public housing.

The structural brutality and discrimination of ten lead to fear, mistrust, and skepticism among asylum seekers with the system, often lying about their conditions to the advocates as well (Hynes, 2003). The violence ranges from physical tortures to mental traumas. There has been a lot of coverage about tear gas, isolation, and even abuses in the detention camp and the shores. There has been an existence of structural violence and oppression (Crawford et al., 2016).

According to my lived experience, coming from a CALD community in Australia; I have witnessed a lot of hate towards asylum seekers. The sole reason being the people from my community reflecting on how difficult it was for them to settle in Australia. They had to accumulate certain points to be eligible for the Permanent Residency. They accuse asylum seekers of having everything ready for them whereas the people from my community do not try to investigate their hardships how they arrive and how the life of those people was in their home country. Asylum seekers are not acknowledged in my community. Also, because 'asylum' is synonymous with 'Islam' in my community and xenophobia exists throughout the community.

\section{Asylum Seekers and Social Work}

The anti-oppressive theory seeks to oppose the underlying institutional and structural challenges in society and power to maintain power balance among minorities (Rogers. 2012). The approach is focused on social justice. Social justice is attained by improving not only the quality of life but also the wellbeing of micro, macro, and mezzo levels with this approach. The fundamental value of diversity is also maintained (Houston \& Marshall, 2020). The abuse of power among the members of the society with regards to asylum seekers strengthens the notion of oppression; hence the approach strives for the power redistribution by not only defying the structures but also by advocating for the rights of the oppressed. The oppression can arise because of the traditional functioning ways of the systems or individuals' bigotry (Hinson \& Bradley, 2020). Asylum seekers in Australia are marginalized by the structure through their stern policies and by individual's bigotry through their hate and sense of threat.

Asylum seekers are socially disadvantaged, most of the time stateless and vulnerable, so, an antioppressive approach is a crucial approach as it seeks to respond to the repression faced by the exploited class. The approach is built on values and ethics linked to the AASW Code of Ethics that incorporate 
DOI: https://doi.org/10.47405/aswj.v5i4.154

respect to human value and dignity, social justice, collaboration, equality, and empowerment (AASW, 2010).

The foundation of social work principles, that endeavors for the diminishment and eradication of prejudice and repression by eliminating the impediments that intercept individuals from basic to additional services is called anti-discriminatory practice (Graham \& Schiele, 2010). Discrimination can be both overt (identified easily) and covert (difficult to identify) (Lennartz, Proost \& Brebels, 2019). Overt discrimination with asylum seekers can be deporting them or putting them into prisons and using punitive measures; such discriminations can be recognized clearly. Covert discrimination with asylum seekers can be the policies of the government that is shown as an aid such as Temporary Protected Visas but using harsh measures as stated about like lack of education, housing; such discriminations cannot be recognized easily. The latter might look as there is no unfairness at all whereas overt discrimination looks violent.

According to the AASW Code of Ethics, social work is dedicated in the quest of and preservation of the welfare of individuals by boosting the growth of human capability and the achievement of human needs, emphasizing the fundamental standards of social work and human rights; respect of human dignity and diversity (AASW, 2010). Social workers are directly engaged with human rights issues and witness the sufferings of the oppressed whose human and constitutional rights have been infringed and neglected. Social workers strive for the emancipation and safeguarding of those oppressed people. While working with asylum seekers, social workers play the role of the advocate in a structural level to overcome the systemic repressions and promote social justice. Social workers need to be constructive nuisances for the oppressors. We as a professional have the accountability to go further individual casework and enhance the wider structure. As we are taken to journeys which are often challenging for government officials, in this case, asylum seekers' challenges, we need to question critically about the injustice and assist in enhancing the system.

\section{References}

AASW.(2010). Code of Ethics. Melbourne: Australian Association of Social Workers

Asylum Insight. Evolution of Asylum Policy in Australia. n.d. https://www.asyluminsight.com/evolutionofasylumpolicy/?rq=evolution\#.XrZRE2gzbIV (accessed May 8, 2020).

Australian Human Rights Commission. (2004). Australia's Immigration Detention Policy and Practice, May 13, 2004. https://humanrights.gov.au/our-work/6-australias-immigration-detention-policyand-practice (accessed May 8, 2020).

Centre for Policy Development. (2014). Beyond the boats: building an asylum and refugee policy for the long term. Weston: Australia 21, 2014.

Copland, S. (2014). Comment: Why do we hate asylum seekers? https://www.sbs.com.au/news/comment-why-do-we-hate-asylum-seekers (accessed May 9, 2020).

Crawford, E., Merrill, T., Shoba, N., Emily, S. \& Durand, J.L. (2016). "The structural-personal interaction: Occupational deprivation and asylum seekers in Australia." Journal of Occupational Science 23, no. 3 (2016): 321-338.

Davidson, H. \& Saba, V. (2018). UN body says Australia breached human rights laws and needs to review Migration Act. https://www.theguardian.com/australia-news/2018/oct/16/un-body-saysaustralia-breached-human-rights-laws-and-needs-to-review-migration-act (accessed May 8, 2020).

Doherty, B. \& Hekmat, A.K. (2016). We are the forgotten people': the anguish of Australia's 'invisible' asylum seekers. https://www.theguardian.com/australia-news/2016/apr/13/we-arethe-forgotten-people-the-anguish-of-australias-invisible-asylum-seekers (accessed May 9, 2020).

Gauja, A., Chen, P., Curtin, J. \& Pietsch, J. (2018). Double Disillusion: The 2016 Australian Federal Election. Canberra: ANU Press 
DOI: https://doi.org/10.47405/aswj.v5i4.154

Graham, M. \& Schiele, J.H. (2010). Equality-of-oppressions and anti-discriminatory models in social work: reflections from the USA and UK." European Journal of Social Work 13, no. 2 (2010): 231-244.

Hartley, L K., Pedersen, A., Fleay, C. \& Hoffman, S. (2013). The situation is hopeless; we must take the next step": Reflecting on social action by academics in asylum seeker policy debate." December 2, 2013. https://groups.psychology.org.au/Assets/Files/Hartley_et_al_ACP_2_13.pdf (accessed May 8, 2020).

Hinson, S. \& Bradley, A. (2010). A Structural Analysis of Oppression. n.d. https://www.racialequitytools.org/resourcefiles/structural_analysis_oppression.pdf (accessed May 9, 2020).

Houston, S, \& Marshall, G. (2010). Developing Anti-Oppressive Practice with the Person-in-Society: Reflexivity and Social Work." Irish Journal of Applied Social Studies 20, no. 1 (2020): 1-16.

Hynes, T. (2003). The issue of 'trust' or 'mistrust' in research with refugees: choices, caveats and considerations for researchers . Geneva: United Nations High Commissioner for Refugees.

Karlsen, E. (2016). Australia's offshore processing of asylum seekers in Nauru and PNG: a quick guide to statistics and resources." December 19, 2016. https://www.aph.gov.au/About_Parliament/Parliamentary_Departments/Parliamentary_Library/ pubs/rp/rp1617/Quick_Guides/Offshore (accessed May 8, 2020).

Lennartz, C., Proost, K. \& Brebels, L. (2019). "Decreasing overt discrimination increases covert discrimination: Adverse effects of equal opportunities policies." International Journal of Selection and Assesment 27, no. 2 (2019): 129-138.

Linklater, A. (2011). Prudence and principle in international society: reflections on Vincent's approach to human rights." International Affairs 87, no. 5 (2011): 1179-1191.

Markus, A. B, \& Dharma, A. (2018). Australian public opinion on asylum." Migration and development 7, no. 3 (2018): 435-447.

Marr, D. \& Doherty, B. (2011). We will decide who comes to this country'. August 20, 2011. https://www.smh.com.au/national/we-will-decide-who-comes-to-this-country-201108191j2cj.html (accessed May 8, 2020).

Marston, G. (2003). Rethinking Social Inequality: the Case of 'Illegal Refugees'. Sydney: Macquarie University.

Medhora, S, \& Doherty, B. (2015). Australia confirms 15 boats carrying 429 asylum seekers have been turned back. January 28, 2015. https://www.theguardian.com/australianews/2015/jan/28/australia-confirms-15-boats-carrying-429-asylum-seekers-have-been-turnedback (accessed May 8, 2020).

Pedersen, A. \& Hartley, L.K. (2015). Can We Make a Difference? Prejudice Towards Asylum Seekers in Australia and the Effectiveness of Antiprejudice Interventions." Journal of Pacific Rim Psychology 9, no. 1 (2015): 1-14.

Phillips, J. (2015). Asylum seekers and refugees: what are the facts?. https://www.aph.gov.au/About_Parliament/Parliamentary_Departments/Parliamentary_Library/ pubs/rp/rp1415/AsylumFacts (accessed May 8, 2020).

Phillips, J, \& Harriet, S. (2013). Boat arrivals in Australia since 1976." July 2013, https://www.aph.gov.au/About_Parliament/Parliamentary_Departments/Parliamentary_Library/ pubs/rp/rp1314/BoatArrivals (accessed May 8, 2020).

Phipps, C. (2015). Did Australia pay people-smugglers to turn back asylum seekers? June 17, 2015. https://www.theguardian.com/world/2015/jun/17/did-australia-pay-people-smugglers-to-turnback-boats (accessed May 8, 2020).

Refugee Council of Australia. (2019). A platform for change: Reforming Australian refugee policy. June 12, 2019. https://www.refugeecouncil.org.au/platform-change/3/ (accessed May 8, 2020).

Refugee Council of Australia. (2020). Denying family reunion for refugees: Impact of Direction 80." April 15, 2020. https://www.refugeecouncil.org.au/direction-80/ (accessed May 8, 2020).

Rogers, J. (2012). Anti-Oppressive Social Work Research: Reflections on Power in the Creation of Knowledge. Social Work Education: The International Journal 31, no. 7 (2012): 866-879.

Taylor, S. (2002). Guarding The Enemy From Oppression: Asylum-Seeker Rights Post-September 11. Melbourne: La Trobe University 
DOI: https://doi.org/10.47405/aswj.v5i4.154

Topsfield, J. (2015). Indonesia to Australia: 'You signed the UN Convention on Refugees. Act on it'. $2015 . \quad$ https://www.smh.com.au/politics/federal/indonesia-to-australia-you-signed-the-unconvention-on-refugees-act-on-it-20150521-gh6u58.html (accessed May 9, 2020).

UNHCR. Article 31 of the 1951 Convention relating to the Status of Refugees: Non-penalization, Detention and Protection. Geneva: United Nations High Commissioner for Refugees, 1951.

Ziersch, A, Clemence, D. \& Moira, W. (2020). Discrimination: a health hazard for people from refugee and asylum-seeking backgrounds resettled in Australia. London: BMC Public Health 